\title{
ЦИВІЛЬНО-ПРАВОВІ ДОГОВІРНІ ВІДНОСИНИ З НАДАННЯ МЕДИЧНИХ ПОСЛУГ
}

Болокан I. B.

\section{ВСТУП}

Майже кожна людина стикається у своєму житті 3 необхідністю звернення до фахівців у сфері медицини за вирішенням тієї чи іншої проблеми, пов'язаної з ії здоров'ям. Зважаючи на те, що держава Україна визнає людину найвищою соціальною цінністю (ст. 3 Конституції України ${ }^{1}$ ), охорона іï життя та здоров'я стає пріоритетним напрямом діяльності держави (ч. 1 ст. 4, ст. 12 Основ законодавства України про охорону здоров'я), щодо якого вона бере на себе низку зобов'язань, зокрема закріплюе гарантії в нормативних актах (ст. ст. 5, 7 Основ законодавства України про охорону здоров'я ${ }^{2}$ ). Здоров'я людини внаслідок своєї комплексності є об'єктом дослідження багатьох наук, серед яких і правова сфера ${ }^{3}$, і як об'єкт охорони та захисту включається у сферу регулювання значної кількості галузей права, отже, сфера забезпечення реалізації права на охорону здоров'я та безпосередньо його захист, $\epsilon$ комплексною. Одним з аспектів, з яким пов'язується охорона здоров'я, $\epsilon$ медичне обслуговування, а через те, що відповідні відносини опосередковуються укладанням певних домовленостей (договори), ці договірні відносини мають цивільно-правову природу. Отже, актуальним напрямом наукових розробок є і залишатиметься аналіз норм права, якими регулюються договірні відносини між замовниками/пацієнтами/клієнтами та медичними установами або фізичними особами-підприємцями, які мають право надавати конкретні (ті, що цікавлять замовника/ пацієнта/клієнта в даний період часу) медичні послуги.

Метою дослідження $є$ обгрунтування на підставі аналізу норм законодавства, якими регулюються ті чи інші аспекти договірних відносин із надання медичних послуг, а також новітніх наукових фахових розробок

\footnotetext{
1 Конституція України від 28 червня 1996 р. (із змінами). URL: https://zakon.rada.gov.ua/laws/ show $/ 254 \% \mathrm{D} 0 \% \mathrm{BA} / 96-\% \mathrm{D} 0 \% \mathrm{~B} 2 \% \mathrm{D} 1 \% 80$ ?find=1\&text=\%D0\%BD\%D0\%B0\%D0\%B9\%D0\%B2\%D0\%B8\% D1\%89\#w11 (дата звернення: 19.05.2020).

2 Основи законодавства України про охорону здоров'я : Закон України від 19 листопада 1992 р. (із змінами). URL: https://zakon.rada.gov.ua/laws/main/2801-12 (дата звернення: 19.05.2020).

${ }^{3}$ Болокан И. Здоровье как объект гражданско-правовой охраны и защиты. Правовая культура в современном обществе : сборник научных статей. Могилев : Могилевский институт МВД, 2019. C. $147-152$.
} 
iз цих питань, цивілістичної природи таких послуг і опосередковуваних ними договорів виявлення недоліків нормативного врегулювання цих питань, формулювання пропозицій 3 удосконалення законодавства у відповідній частині. Методологія дослідження базується на засадах порівняльно-правового, формально-логічного та системного аналізу, 3 використанням методів моделювання, аналізу та синтезу.

Постановка проблеми. Попри той факт, що договори з надання медичних послуг $\epsilon$ чи не найпоширенішими в повсякденному житті договорами, у базовому кодифікованому акті приватного права - Цивільному кодексі України (далі - ЦК України) - цей договір окремо не регулюється. Про медичне обслуговування в ньому згадується лише один раз (у нормі про публічні договори), урегулювання нормами ЦК України здійснюється на підставі узагальнюючих норм, тобто тих, якими регулюються договори про надання послуг загалом (за умови підходу до медичних послуг як до різновиду цивільно-правових послуг). Іншим кодифікованим актом, у якому йдеться про охорону здоров'я та згадується про договірні відносини, є Основи законодавства України про охорону здоров'я, де йдеться про дещо інші аспекти відносин медичного обслуговування. Так, у ньому закріплено норми про договірні відносини медичного обслуговування населення, а сторонами цих договорів $\epsilon$ головні розпорядники бюджетних коштів (замовником відповідних послуг є держава або органи місцевого самоврядування) та заклади охорони здоров'я і фізичні особи-підприємці, які зареєстровані й одержали в установленому законом порядку ліцензію на провадження господарської діяльності з медичної практики (ст. 18 Основ законодавства України про охорону здоров'я $\left.{ }^{4}\right)$. Тобто в Основах законодавства України про охорону здоров'я не йдеться про нормативне врегулювання договірних відносин із надання конкретної, необхідної фізичній особі в певний момент часу медичної послуги, із «прописуванням» зобов'язань сторін щодо цієї послуги, умов про відповідальність за невиконання або неналежне виконання взятих на себе зобов'язань, інших важливих питань, тобто не йдеться про договір, у якому було б конкретизовано предмет (конкретна медична послуга) та прописані істотні й інші умови відповідних договірних відносин.

Аналіз джерел та останніх досліджень. Аналіз тематичних джерел дозволяє умовно виокремити кілька наукових напрямів у дослідженні відповідного питання. Перший напрям безпосередньо пов'язаний 3 аналізом таких змістовних за обсягом блоків, як зміст цивільних правовідносини, що виникають у сфері здійснення медичної діяльності;

\footnotetext{
${ }^{4}$ Основи законодавства України про охорону здоров'я : Закон України від 19 лситопада 1992 р. (із змінами). URL: https://zakon.rada.gov.ua/laws/main/2801-12 (дата звернення: 19.05.2020).
} 
характеристика медичної послуги як об'єкта цивільних правовідносин (С. Булеца (2016 р.), В. Савченко (2014 р.), М. Самофал $(2014 \text { р.) })^{5}$. Другий напрям характеризується представленням аналізу саме договірних відносин, які мають місце у сфері медицини (А. Герц (2016 р.), О. Смотров $(2003 \text { р.) })^{6}$. Третій напрям виізняється вузькоспеціалізованим спрямуванням дослідження й акцентом лише на окремих складових частинах медичного обслуговування, зокрема на цивільно-правових аспектах здійснення права на медичну допомогу (як складову частину медичного обслуговування) або на аналізі особливостей конкретних медичних послуг (Т. Волинець (2008 р.), А. Тараненко (2015 р.)) ${ }^{7}$. Четвертий напрям представлений дослідженнями негативних наслідків медичного обслуговування, зокрема завдання шкоди здоров'ю наданням таких послуг, питанням цивільноправової відповідальності в медичній сфері (С. Книш (2018р.), Д. Микитенко, I. Гомля (2018р.), Х. Майкут (2017р.), В. Кушнір, Н. Коробцова (2019 р.), С. Михайлов (2010 р.), Г. Оверко (2012 р.) ${ }^{8}$ У У даній публікації надається комплексний аналіз особливостей цивільно-правових договірних відносин із надання медичних послуг з узагальненням положень наведених напрямів наукових досліджень обраної проблематики.

\section{1. Медична послуга як різновид цивільно-правових послуг}

Серед термінів, нормативно визначених в Основах законодавства України про охорону здоров'я, термін «медичне обслуговування», зі змісту якого вбачається, що відповідна діяльність здійснюється обмеженим колом суб'єктів (заклади охорони здоров'я та фізичні особи-підприємці, які зареєстровані й одержали відповідну ліцензію) та в певній сфері (сфера

\footnotetext{
5 Булеца С. Цивільні правовідносини, що виникають у сфері здійснення медичної діяльності: теоретичні та практичні проблеми : автореф. дис. ... докт. юрид. наук: 12.00.03. Одеса, 2016. 40 с. С. 4-9 ; Савченко О. Медичні послуги як об’єкт цивільних правовідносин : автореф. дис. ... канд. юрид. наук: 12.00.03. Київ, 2014. 20 с. С. 3-5 ; Самофал М. Цивільно-правове регулювання надання медичних послуг дітям : автореф. дис. ... канд. юрид. наук: 12.00.03. Київ. 2014. 18 с.

${ }^{6}$ Герц А. Договірні зобов'язання у сфері надання медичних послуг : дис. ... докт. юрид. наук: 12.00.03. Київ. 2016. 421 с. С. 10-13 ; Смотров О. Договір щодо сплатного надання медичних послуг : автореф. дис. ... канд. юрид. наук: 12.00.03. Харків, 2003. 20 с. С. 6-7.

7 Волинець Т. Цивільно-правові засоби здійснення права на медичну допомогу : автореф. дис. ... канд. юрид. наук: 12.00.03. Львів, 2008. 16 с. С. 3-4 ; Тараненко А. Договір на протезування органів та кінцівок людини : дис. ... канд. юрид. наук: 12.00.03. Київ. 2015. 253 с. С. 8-13.

${ }^{8}$ Книш С. Юридична відповідальність за правопорушення у сфері охорони здоров'я в Україні. Право $i$ безпека. 2018. № 4 (71). C. 43-49. DOI: 10.32631/pb2018.4.05 ; Микитенко Д., Гомля I. Проблемні питання відповідальності за шкоду, завдану при вакцинації. Мистецтво наукової думки. 2018. № 1. С. 140-143 ; Майкут Х. До питання цивільно-правової відповідальності у сфері медичної діяльності. Науковий вісник Херсонського державного університету. Серія «Юридичні науки». 2017. Вип. 1. Т. 1. С. 88-91 ; Кушнір В., Коробцова Н. До питання цивільно-правової відповідальності у сфері надання медичних послуг. Молодий вчений. 2019. № 11 (75). С. 42-46. DOI: 10.32839/2304-5809/2019-11-75-10 ; Михайлов С. Цивільно-правова відповідальність у сфері надання медичних послуг : автореф. дис. ... канд. юрид. наук: 12.00.03. Харків, 2010. 17 с. С. 6-7 ; Оверко Г. Відшкодування моральної шкоди, заподіяної при наданні медичних послуг в Україні : автореф. дис. ... канд. юрид. наук: 12.00.03. Київ, 2012. 19 с.
} 
охорони здоров'я), а поняття «медичне обслуговування» $\epsilon$ більш змістовним, аніж поняття «медична допомога», адже таке обслуговування не обов'язково обмежується наданням медичної допомоги, але безпосередньо пов'язане з ії наданням (нормативна дефініція у ст. 1 Основ законодавства України про охорону здоров'я9). Хоча на підставі аналізу тих самих норм у наукових джерелах робиться й протилежний висновок про те, що поняття «медична допомога» ширше й охоплює медичні послуги ${ }^{10}$.

В Основах законодавства України про охорону здоров’я також ідеться про «договори про медичне обслуговування», натомість у цій публікації йдеться про дещо інші договори - не загальну домовленість про можливість звернення по медичну допомогу визначених видів, а про конкретні випадки надання кожної окремої медичної послуги. У такому розумінні (саме як конкретна домовленість про певну медичну послугу) сприймаються випадки звернення до приватних медичних клінік, мабуть, тому що особа сплачує за це власні кошти, отже, очікує на якісні послуги. Звернення ж до державних клінік, де громадяни зазвичай не сплачують безпосередньо власні кошти за медичну допомогу (у таких клініках найчастіше йдеться саме про медичну допомогу, і рідше - про інші медичні послуги), громадяни не так чітко сприймають медичне обслуговування як цивільно-правові договори про надання медичних послуг, хоча i в першому, і у другому випадках мають місце саме такі договірні відносини. Одним із чинників, що не сприяє усвідомленню цивільно-правового змісту таких договорів пересічними громадянами, $\epsilon$ те, що домовленості про надання певної медичної послуги зазвичай не оформлюються письмово. Але й інші послуги побутового характеру також часто не оформлюються письмово, наприклад, відносини побутового підряду, хоча в цьому разі вони сприймаються як цивільно-правові саме завдяки оплаті таких послуг власним коштом. Отже, поєднання двох чинників - відсутності письмового оформлення та відсутності сплати безпосередньо власним коштом (а не через відносини «сплата податків кожним громадянином та оплата послуг медичних фахівців бюджетними коштами») - часто й ускладнюють сприйняття надання/отримання медичних послуг/допомоги як укладення й виконання цивільно-правових договорів.

У ЦК Українине немає окремої глави, яка б присвячувалась урегулюванню договорів про надання медичних послуг. У підр. I розд. III кн. V ЦК України є чимало договірних конструкцій, за допомогою яких

\footnotetext{
${ }^{9}$ Основи законодавства України про охорону здоров'я : Закон України від 19 листопада 1992 p. (із змінами). URL: https://zakon.rada.gov.ua/laws/main/2801-12 (дата звернення: 19.05.2020)

10 Пташник I. Трансплантація органів як особливий вид медичної послуги. Актуальні проблеми вдосконалення чинного законодавства України. 2016. Вип. 41. С. 16-26. С. 21.
} 
оформлюється надання різного роду послуг, проте про медичні послуги у ЦК України не йдеться. Однак це не означає, що ті послуги, які надаються медичними установами або фізичними особами-підприємцями у сфері охорони здоров'я, не $\epsilon$ цивільно-правими послугами. Здійснюючи сходження від загального до спеціального, можна продемонструвати принаймні два аспекти, які характеризують цивільно-правову природу медичних послуг, а саме: 1) «цивільно-правова послуга» $\rightarrow$ «медична послуга»; 2) «цивільноправовий договір» $\rightarrow$ «конкретний договір із надання певної медичної послуги (послуги «традиційної» або «нетрадиційної» медицини)».

Щодо першого аспекту - «цивільно-правова послуга» $\rightarrow$ «медична послуга» - зазначимо, що остання включає варіанти розгляду і як окремих незалежних, і як поєднаних один з одним різновидів діяльності з медичної профілактики, медичної допомоги, медичного оздоровлення. Такий висновок випливає 3 аналізу нормативних дефініцій «медичне обслуговування» та «медична допомога», наданих в Основах законодавства України про охорону здоров'я. Останнє поняття нині поєднує два поняття, які раніше визначались у цьому кодифікованому акті (тоді ще не було нормативного визначення терміна «медична допомога», закріплювались такі поняття, як «медико-санітарна допомога» та «лікувально-профілактична допомога», які згодом і було включено в дефініцію «медична допомога»). Отже, у контексті аналізу предмета договору про надання медичних послуг ним можуть бути: 1) послуги із профілактики, метою отримання яких із боку замовника/клієнта $\epsilon$ наявність такого стану здоров'я, який характеризується відсутністю фізичних хвороб; 2) послуги з оздоровлення, метою отримання яких із боку замовника/пацієнта $є$ відновлення здоров'я, коли має місце певний «ненормальний» стан здоров'я, який треба повернути в первісний чи схожий до первісного стан; 3) поліпшення (удосконалення) стану здоров' $я{ }^{11}$.

Аналіз цього аспекту потребує відповіді на питання, чи можна медичні послуги вважати цивільно-правовими послугами, позитивна відповідь на яке стає можливою лише після здійснення аналізу відповідності ознак медичних послуг ознакам цивільно-правових послуг, адже «послуга не існує абстрактно, є об'єктивною правовою категорією, яка характеризується низкою ознак». ${ }^{12}$ Питанням ознак цивільно-правових послуг присвячено чимало праць авторитетних учених-цивілістів. Аналіз норм цивільного законодавства та доктринальних положень щодо ознак цивільно-правових

\footnotetext{
11 Болокан I. Послуги нетрадиційної медицини як різновид цивільно-правових послуг. Запорізькі правові читання : матеріали щорічної Міжнародної науково-практичної конференції, м. Запоріжжя, 6 травня 2019 р. Запоріжжя : ЗНУ, 2019. 137 с. С. 12-16.

12 Скрипник В. Послуги як особливий об'єкт цивільних прав. Науковий вісник Міжнародного гуманітарного університету. Серія «Юриспруденція». 2018. № 36. Т. 2. С. 38-41.
} 
послуг як самостійного об'єкта цивільних прав (ст. 177 ЦК України ${ }^{13}$ ), дозволяє стверджувати, що медичні послуги як різновид цивільно-правових послуг мають нематеріальний характер, результат яких не набуває уречевлюваного вигляду (тобто не є окремим предметом матеріального світу), адже більшість конкретних дій виконавця таких послуг неможливо зафіксувати. Зазвичай $є$ певний ефект (може бути як позитивним, так i негативним) від застосування знань медичного персоналу, інших суб'єктів, які безпосередньо надають медичні послуги. Це може бути рекомендація конкретних ліків, здійснення певних дій (наприклад, оперативне втручання), момент надання та споживання послуги в яких збігається, а іiі результат не набуває матеріальної форми. У наукових джерелах можна натрапити на підхід до такого «ефекту» як до певного результату дії або сукупності дій (діяльності) $^{14}$, а також обгрунтування матеріальної складової частини дій медичного характеру через їхній вплив на стан предметів матеріального та нематеріального світу ${ }^{15}$, виокремлення двох можливих предметів послуг «лікування» та «вилікування», у яких різний ефект від послуги ${ }^{16}$, натомість суть цієї ознаки не оспорюється.

Відповідають медичні послуги й іншим ознакам цивільно-правових послуг, серед яких безпосередня пов'язаність з особою, яка відповідні послуги надає (що може проявлятися в різних формах, від звернення до конкретного спеціаліста (персоналізація лікаря, так би мовити, «прив'язка» до конкретного прізвища) до звернення просто до будь-якої особи, яка $\epsilon$ фахівцем у певній галузі медицини (наприклад, до лікаря-ендокринолога чи лікаря-отоларинголога, та ін.). Попри відсутність матеріалізації (немає конкретного предмета матеріального світу), для медичної послуги, як і для будь-якого іншого різновиду цивільно-правової послуги, характерна наявність результату, який має конкретні характеристики в контексті якісних змін в об'єкті (під об'єктом розуміємо здоров'я конкретної людини) - покращення чи погіршення стану після звернення за наданням медичної послуги.

Досить специфічний прояв щодо медичних послуг має така ознака цивільно-правових послуг, як досягнення корисного i правомірного

\footnotetext{
13 Цивільний кодекс України від 16 січня 2003 р. (із змінами). URL: https://zakon.rada.gov.ua/ laws/show/435-15 (дата звернення: 19.05.2020).

${ }^{14}$ Федорченко Н. До питання про предмет договору про надання послуг. Держава $і$ право. Юридичні $i$ політичні науки. Вип. 66. С. 165-173.

15 Савченко В. Характерні правові ознаки медичних послуг. VIII Miжнародна наукова Internetконференції студентів та молодих вчених. Харків : ХНУ імені В.Н. Каразіна, 2013. С. 451-453. URL: http://dspace.univer.kharkov.ua/handle/123456789/8486 (дата звернення: 19.05.2020).

${ }_{16}$ Майданник Р., Пермяков Б. Договір про надання медичних послуг. Аномалї в ицивільному праві України : навчально-практичний посібник / за заг. ред. Р. Майданника. 2-ге вид., перероб. та доп. Київ : Юстініан, 2010. 1008 с. С. 292.
} 
результату наданням послуги. Дискусії можуть точитися як щодо першої складової частини цієї ознаки (досягнення корисного результату), так і щодо другої (правомірність результату). Безсумнівна ідеальна мета досягнення корисного результату (у контексті розуміння «корисності» як «добрих (позитивних) наслідків» ${ }^{17}$ ), про яку можна вести мову лише за умови добросовісності суб'єкта, який надає відповідну медичну послугу. Водночас уживання нами слова «добросовісність» також дещо умовне, адже може стосуватися лише фізичних осіб, оскільки пов'язане із поняттям «совість». Натомість маємо на увазі прагнення надати саме якісну послугу. А «мірилом» якості надання медичних послуг є саме здоров'я людини його покращення або підтримка в наявному стані, залежно від того, про яку конкретно медичну послугу (профілактика чи лікування) ідеться. Коли йдеться про користь (для здоров'я людини) результату медичної послуги, варто зважати на той факт, що в питаннях оздоровлення та медичної допомоги ніхто ніколи не гарантуватиме стовідсотковий результат, що пов'язано з індивідуальними особливостями кожної конкретної людини, неможливістю спрогнозувати ефект від лікувальних чи профілактичних заходів на організм конкретної людини. Але в такому разі можна проводити аналогію з будь-якими іншими послугами. Загалом, коли замовник звертається за наданням будь-якої послуги, він очікує саме позитивний (якісний для себе) від іiі отримання результат. Це саме стосується й медичних послуг. Щодо правомірності надання медичних послуг, тут аномалії можуть виникати лише щодо суб'єкта надання відповідної послуги (він має підтвердити наявність ліцензії на здійснення відповідних послуг) та видів діяльності, які здійснюються (у межах наявних і підтверджених знань та навичок виконавця послуги). У всіх інших випадках питання про правомірність не мають виникати. Отже, попри певну специфіку, медичні послуги загалом відповідають вказаним ознакам цивільно-правових послуг.

Ще одна ознака цивільно-правових послуг, яка найчастіше виокремлюється вченими-цивілістами, $€$ їхня оплатність. Ця тема неодноразово висвітлювалась у наукових джерелах, і загальним висновком $\epsilon$ відповідність медичних послуг цій ознаці, адже незалежно від того, ким оплачується послуга, самим клієнтом/пацієнтом, іншою фізичною особою за клієнта/пацієнта, юридичною особою за клієнта/пацієнта (наприклад підприємством за своїх працівників), державою (як це має місце щодо значного обсягу різновидів медичної допомоги, яка надається населенню),

\footnotetext{
${ }^{17}$ Великий тлумачний словник української мови / упоряд. Т. Ковальова. Харків : Фоліо, 2005. 767 с. C. 296-297.
} 
послуга має свою вартість ${ }^{18}$, передбачає іï сплату. I чітке розмежування оплатності/безоплатності договору можливе лише 3 погляду суб'єкта сплати, якщо сам клієнт/пацієнт не сплачує, він сприймає цю послугу як безоплатну, натомість це не означає безоплатності надання такої послуги

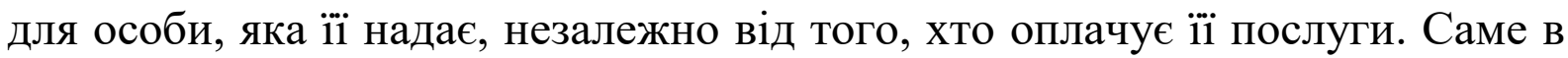
такому контексті про безоплатність надання медичної допомоги в державних та комунальних закладах охорони здоров'я, яке гарантується державою, про надання необхідних медичних послуг і лікарських засобів державним коштом ідеться у ст. 8 Основ законодавства України про охорону здоров'я. Щодо профілактики, прикладом безоплатних медичних послуг є положення ст. 53 Основ законодавства України про охорону здоров'я ${ }^{19}$, де закріплено обов'язок закладів охорони здоров'я здійснювати спеціальні заходи профілактики та лікування соціально небезпечних та карантинних захворювань. У доктрині цивільного права під час класифікації договорів у медичній сфері наведені ситуації відносять до договорів про безоплатне надання медичної допомоги ${ }^{20}$.

Тобто медична послуга постає у вигляді певного «товару», який сплачується (безпосередньо оплата стосується знань, навичок та часу лікаря або іншого фахівця у сфері охорони здоров'я), адже $\epsilon$ запит замовника на вирішення якоїсь конкретної проблеми, що пов'язується 3 діями, консультацією відповідного лікаря чи іншого суб'єкта, що надає конкретну медичну послугу. Загальним правилом, яке нормативно закріплене у ЦК України, є оплатність цивільно-правових послуг. На відміну від послуг «нетрадиційної» медицині, послуги «традиційної» медицини передбачають зазвичай грошову форму оплати. Важливість так званого «ціного блока договору» зазначається як у наукових джерелах, так i в рекомендаціях практиків, адже «оплата медичних послуг пов'язується 3 певним кошторисом, який є планом лікування ${ }^{21}$, а сама медична послуга має вартісний вираз, що відрізняє іiї від медичної допомоги» ${ }^{22}$.

Наведені міркування свідчать про те, що медичні послуги відповідають низці ознак цивільно-правових послуг, отже, $\epsilon$ їх різновидом. Їм притаманні й специфічні визначальні риси, які в доктрині цивільного права

18 Тараненко А. Договір на протезування органів та кінцівок людини : дис. ... канд. юрид. наук: 12.00.03. Київ, 2015. 253 с. С. $31,131$.

19 Основи законодавства України про охорону здоров'я : Закон України від 19 листопада 1992 р. (із змінами). URL: https://zakon.rada.gov.ua/laws/main/2801-12 (дата звернення: 19.05.2020).

${ }^{20}$ Майданник Р. Договір про надання медичних послуг: загальні положення. Медичне право. 2016. № 1 (16). С. 139-158.

${ }^{21}$ Герц А. Ціна як істотна умова договору про надання платних медичних послуг. Юридичний вісник. 2015. № 1. С. 115-118.

22 Щодо укладання договорів про надання платних медичних послуг. URL: https://kr.gov.ua/ua/news/pg/220917308767281_s (дата звернення: 19.05.2020). 
пов'язуються 3 особливістю блага, щодо якого послуга надається; 3 відсутністю цілковитих гарантій в отриманні очікуваного результату; 3 неможливістю стандартизації ${ }^{23}$. Інший важливий висновок полягає в тому, що цей різновид цивільно-правових послуг є надто специфічним, щоб можливе було залишення того стану, який має місце нині, - відсутності чіткого нормативного врегулювання договорів, якими опосередковуються відповідні послуги.

\section{2. Договір про надання медичних послуг як різновид цивільно-правових договорів}

Розкриваючи другий аспект цивільно-правової природи медичної послуги як різновиду цивільно-правових послуг, зупинимось на аналізі такого ланцюжка цих відносин, як «цивільно-правовий договір» $\rightarrow$ «конкретний договір із надання певної медичної послуги». Про те, що медичні послуги є цивільно-правовими, опосередковано свідчить і факт перелічення серед різновидів публічних договорів у ст. 633 ЦК України послуг із медичного обслуговування ${ }^{24}$. Оскільки, як уже зазначалось, окремої глави, норми якої безпосередньо б регулювали договір про надання медичних послуг, у ЦК України немає, застосовувати варто загальні положення ЦК України (про послуги як об'єкт цивільних прав, про договори знадання послуг, про договори загалом, про зобов'язання, про правочини тощо).

Проблемним питанням у сфері договірних відносин медичної спрямованості $\epsilon$ те, що договори про надання конкретних медичних послуг часто не укладаються в письмовій формі, що в подальшому значно ускладнює вирішення спорів, коли одна зі сторін (а це найчастіше саме пацієнт/клієнт) позиватиметься про неналежну якість наданих медичних послуг або й узагалі - про відшкодування збитків, які є наслідком надання відповідної медичної послуги.

Особливістю нормативного регулювання договорів про надання медичних послуг $є$ те, що попри наявність двох базових кодифікованих актів - ЦК України й Основ законодавства України про охорону здоров'я питання договірного врегулювання відповідних відносин у них визначені фрагментарно та безсистемно. Можна навіть стверджувати, що найважливіші питання чітко не врегульовані. До найважливіших питань відносимо питання про предмет, оплатність, форму договору, права й

\footnotetext{
${ }^{23}$ Майданник Р., Пермяков Б. Договір про надання медичних послуг. Аномалії в ичивільному праві Украӥни : навчально-практичний посібник / за заг. ред. Р. Майданника. 2-ге вид., перероб. та доп. Київ : Юстініан, 2010. 1008 с. С. 289.

24 Цивільний кодекс України від 16 січня 2003 р. (із змінами). URL: https://zakon.rada.gov.ua/ laws/show/435-15 (дата звернення: 19.05.2020).
} 
обов'язки суб'єктів цих відносин, відповідальність за невиконання або неналежне виконання зобов'язань за договором, припинення договору тощо. Натомість належне врегулювання саме цих питань, на наш погляд, i є гарантією захисту прав клієнта/пацієнта, прав лікарів, інших суб’єктів, які безпосередньо надають медичні послуги, у разі, коли відносини набувають «негативної спрямованості».

Предмет договору про надання медичних послуг (а саме - послуга як різновид цивільно-правових послуг) і оплатність відповідних договорів у загальних рисах уже було окреслено вище. Тож зупинимось на інших важливих аспектах цих різновидів цивільно-правових договорів.

У ЦК України немає окремої норми з переліком прав і обов'язків сторін договору про надання послуг. Аналіз гл. 63 ЦК України дозволяє виокремити право виконавця (за термінологією ЦК України, сторона, яка надає певну послугу, має назву «виконавець») на покладення виконання договору на іншу особу, залишаючись відповідальним у повному обсязі перед замовником за порушення договору, але для того, щоб скористатись таким правом, необхідно це обумовити. Серед обов'язків виконавця ЦК України передбачає обов'язок надання замовнику певної послуги, обумовленої договором, та надання послуги особисто. Серед обов'язків замовника у ЦК України закріплено лише один - оплатити виконавцеві надану йому послугу в розмірі, у строки та порядку, встановлені договором. Вказане правило стосується оплатних договорів про надання медичних послуг. Оскільки в цивільному законодавстві надається можливість (як виняток) укладення й безоплатних договорів, щодо таких випадків встановлюється правило про те, що розрахунки сторін можуть стосуватися лише відшкодування фактичних витрат виконавця, зроблених ним для виконання договору.

В Основах законодавства України про охорону здоров'я, навпаки, досить багато норм, у яких ідеться про певні права й обов'язки, але більшість із них досить узагальнені і фактично мають низький рівень можливості їх практичного застосування. Інакше кажучи, в Основах законодавства України про охорону здоров'я є низка норм, у яких встановлено права й обов'язки обох сторін, але в них не йдеться про конкретні договірні відносини, конкретні дії. Насамперед в Основах законодавства України про охорону здоров'я згадується про право на охорону здоров'я (ст. $6^{25}$ ). Зазначимо, що це право закріплено і в нормах загальної частини ЦК України (ст. $283^{26}$ ). Не заперечуємо значущість цього

\footnotetext{
${ }^{25}$ Основи законодавства України про охорону здоров'я : Закон України від 19 листопада 1992 p. (із змінами). URL: https://zakon.rada.gov.ua/laws/main/2801-12 (дата звернення: 19.05.2020).

26 Цивільний кодекс України від 16 січня 2003 р. (із змінами). URL: https://zakon.rada.gov.ua/ laws/show/435-15 (дата звернення: 19.05.2020).
} 
права, проте зазначимо лише опосередкований його вплив на безпосередні договірні відносини. Лише окремі з перелічених у відповідних статтях пункти можуть бути взяті за основу та включені у зміст конкретного договору (наприклад, закріплене у ст. 6 Основ законодавства України про охорону здоров'я право на компенсування завданої здоров'ю шкоди). Окремі права, які закріплені в Основах законодавства України про охорону здоров'я, мають значення на переддоговірному етапі, прикладом $\epsilon$ закріплене у ст. 38 Основ законодавства України про охорону здоров'я право на вибір лікаря і закладу охорони здоров'я. Можливість обмеження прав пов'язана з тим, що для держави однаково значну цінність має життя i здоров'я абсолютно кожної людини. Крім цього, варто зазначити, що норми як у ЦК України, так і в Основах законодавства України про охорону здоров'я можуть бути сформульовані як в імперативній, так і в диспозитивній формах. Це не матиме особливого значення тоді, коли не дотримано письмову форму договору, будь-яка домовленість сторін може бути предметом доказування в разі судового вирішення спору. Значення це має тоді, коли сторони щось передбачили в договорі, що відрізняється або навіть суперечить законодавчим положенням. За одночасного врегулювання питання умовами договору й імперативними законодавчими нормами пріоритет матимуть законодавчі норми, особливо це стосується випадків звуження прав будь-якої зі сторін. За одночасного врегулювання питання умовами договору та диспозитивними законодавчими нормами пріоритет матимуть норми договору, адже законодавець передбачив можливість змінити домовленістю сторін законодавчі положення.

Так само досить узагальнено сформульовано й обов'язки громадян у сфері охорони здоров'я (ст. 10 Основ законодавства України про охорону здоров'я). Обов'язок надання достовірної і повної інформації про стан здоров'я пацієнта, зокрема право громадянина на ознайомлення 3 відповідними медичними документами, що стосуються його здоров'я, яке закріплене у ст. 39 Основ законодавства України про охорону здоров'я, безпосередньо пов'язаний із добросовісністю другої сторони договору про надання медичних послуг. Так само пов'язане 3 певними етичними аспектами й право на таємницю щодо стану здоров'я, зокрема стосовно діагнозу, відомостей, одержаних під час медичного обстеження, яке закріплене у ст. 39-1 Основ законодавства України про охорону здоров'я, якому кореспондує обов'язок зберігати лікарську таємницю, що закріплений у ст. 40 Основ законодавства України про охорону здоров'я (договори про надання медичних послуг є двосторонніми, що означає, що обов'язку однієї сторони кореспондує відповідне право іншої сторони). I навіть професійні обов'язки медичних і фармацевтичних працівників, які 
перелічені у ст. 78 Основ законодавства України про охорону здоров'я, досить узагальнені, хоча окремі 3 них і можуть бути використані у формулюваннях конкретних договорів, щоправда, за умови їх деталізації, наприклад, положення про своєчасність та кваліфікованість медичної та лікарської допомоги. Варто зазначити вживання законодавцем оціночних понять у відповідних нормах (у наведеному вище прикладі «своєчасність»).

Відсутність спеціальної глави у ЦК України, присвяченої врегулюванню питань надання медичних послуг, пояснює й відсутність спеціальної норми про форму договору про надання медичних послуг. У такій ситуації застосовувати варто загальні норми ЦК України про форму правочинів (зокрема, ст. 208 ЦК України), відповідно до яких правочини між фізичною та юридичною особою треба вчиняти в письмовій формі. Клієнт/пацієнт завжди є фізичною особою, але укладати договір може й не безпосередньо він, а й інші фізичні чи навіть юридичні особи на його користь. Медичне обслуговування здійснюється закладами охорони здоров'я та фізичними особами-підприємцями. Закладами охорони здоров'я є юридичні особи будь-якої форми власності й організаційноправової форми або ऑiі відокремлені підрозділи (ч. 1 ст. 3 Основ законодавства України про охорону здоров'я ${ }^{27}$ ). Вказане свідчить про необхідність укладення договору про надання медичних послуг у письмовій формі. Щоправда, наведена норма (п. 2 ч. 1 ст. 208 ЦК України ${ }^{28}$ ) передбачає й виняток із цього правила, здійснюючи посилання на ч. 1 ст. 206 ЦК України, де закріплюються випадки, коли правочини можуть учинятися усно, зокрема, якщо вони цілковито виконуються сторонами в момент їх учинення. Отже, можливість укладення договорів в усній формі формально передбачена лише для випадків надання медичних послуг одноразово (у сенсі - за один раз). В інших випадках має дотримуватись письмова форма такого правочину. Якщо ж сторони не дотримались такої форми, особливо негативних наслідків не передбачено, адже договір про надання медичних послуг, як уже неодноразово зазначалось, не врегульований як окремий різновид у ЦК України, отже, застосовуватимуться правила про наслідки недодержання форми правочинів. Визнання таких правочинів недійсними внаслідок недодержання письмової форми у ЦК України не передбачено, адже через відсутність спеціальної норми про форму договорів із надання медичних послуг у ЦК України окремо не обумовлено нікчемність таких правочинів,

\footnotetext{
${ }^{27}$ Основи законодавства України про охорону здоров'я : Закон України від 19 листопада 1992 р. (із змінами). URL: https://zakon.rada.gov.ua/laws/main/2801-12 (дата звернення: 19.05.2020).

28 Цивільний кодекс України від 16 січня 2003 р. (із змінами). URL: https://zakon.rada.gov.ua/ laws/show/435-15 (дата звернення: 19.05.2020).
} 
а в ч. 1 ст. 218 ЦК України закріплено загальне правило про те, що недодержання сторонами письмової форми правочину, яка встановлена законом, не має наслідком його недійсність. Проблеми виникатимуть у разі оспорення будь-якою зі сторін укладеного усно договору, оскільки у вказаній ст. 218 ЦК України йдеться про те, що в такому разі (сторона взагалі заперечує факт наявності домовленості або оспорює зміст цих домовленостей) стороні доведеться доводити (а це вже буде здійснюватись у судовому порядку) дозволеними доказами, серед яких письмові докази, засоби аудіо-, відеозапису, факт укладення відповідного договору та зміст домовленостей між його сторонами. Можливі проблеми для позивача чи відповідача пов'язані із забороною доведення відповідних фактів чи змісту домовленості лише за допомогою показань свідків (законодавче формулювання ч. 1 ст. 218 ЦК України: «рішення суду не може грунтуватися на свідченнях свідків» ${ }^{29}$ ).

Але навіть вказівка про письмову форму правочину не означає укладення його саме у формі такого документа, як договір, адже відповідно до ч. ч. 1, 2 ст. 207 ЦК України, правочин уважається таким, що вчинений у письмовій формі: 1) якщо його зміст зафіксований в одному або кількох документах (зокрема, електронних), у листах, телеграмах, якими обмінялися сторони; 2) якщо воля сторін виражена за допомогою телетайпного, електронного або іншого технічного засобу зв'язку; 3) якщо він підписаний його стороною (сторонами) ${ }^{30}$. Що стосується випадків, коли медичні послуги надаються фізичними особами-підприємцями, вимогу письмової форми відповідного правочину закріплено в п. 3 ч. 1 ст. 208 ЦК України, у якому здійснено «прив'язування» до певної суми (якщо вартість медичної послуги станом на травень 2020 р. перевищує 340 грн, відповідний договір має укладатись у письмовій формі). Наслідки iii недодержання такі ж, які зазначені вище.

3 урахуванням наведених міркувань, зважаючи на особливу цінність об'єкта спрямування послуги - здоров'я людини, обгрунтовуємо необхідність закріплення вимоги про обов'язкову письмову форму для договорів про надання медичних послуг із закріпленням спеціальних наслідків ¥ї недодержання. Звичайно, сторони можуть проігнорувати відповідну вимогу, натомість мають усвідомлювати й можливі наслідки такого ігнорування - нікчемність відповідного правочину. Нині маємо недостатнє врегулювання цього питання. Що дає письмова форма? Насамперед урегулювання питань деталізації прав і обов'язків сторін,

\footnotetext{
29 Цивільний кодекс України від 16 січня 2003 р. (із змінами). URL: https://zakon.rada.gov.ua/laws/ show/435-15 (дата звернення: 19.05.2020).

30 Цивільний кодекс України від 16 січня 2003 р. (із змінами). URL: https://zakon.rada.gov.ua/laws/ show/435-15 (дата звернення: 19.05.2020).
} 
строків, відповідальності за невиконання або неналежне виконання будьякою зі сторін договору про медичне обслуговування своїх зобов'язань за договором. Це значної мірою спростить вирішення спорів у випадках, якщо такий договір матиме елементи інших типів договорів (змішані договори), адже це досить часто має місце на практиці ${ }^{31}$. Свідомий підхід до укладання договору дозволить зменшити кількість випадків використання конструкцій договорів приєднання ${ }^{32}$.

Окремі аспекти правового статусу сторін договору про надання медичних послуг уже було зазначено. Ще одне дискусійне питання щодо «суб'єктного складника» договорів про надання медичних послуг пов'язане з назвою сторін відповідних договорів, адже та термінологія, яка використовується в Основах законодавства України про охорону здоров'я («пацієнт»), не відображає всіх аспектів послуги, охоплює лише ситуації стану «нездоров'я». У цій публікації вживались різні назви щодо одного із суб'єктів договірних відносин із надання медичних послуг - i «замовник», і «пацієнт», і «клієнт», що пов'язано зі специфікою медичної послуги. Якщо йдеться про профілактику хвороб, то узагальнена назва, яка вживається у ЦК України під час регулювання особливостей договорів про надання послуг, - «замовник», у разі укладання договору про надання медичних послуг, спрямованих на зміцнення здоров'я, профілактику хвороб, має трансформуватись у назву сторони «клієнт». Якщо предметом договору про надання медичних послуг $\epsilon$ відновлення здоров'я або безпосередньо медична допомога, можливе використання тієї назви відповідної сторони, яка нині використовується в Основах законодавства України про охорону здоров'я, - «пацієнт». Отже, для позначення сторони, яка за положеннями ЦК України про договори з надання послуг має назву «замовник», може бути залишена ця назва в контексті узагальнюючої назви сторони за договорами про надання медичних послуг загалом, адже, як уже зазначалось, укласти договір можна на свою користь, і в такому разі особа, яка укладає договір, і особа, яка безпосередньо отримує медичну послугу, та сама. У такому разі замовником у договорах про надання медичних послуг завжди буде фізична особа. У свою чергу, якщо замовник водночас отримує послугу (збіг в одній особі), вказана сторона може мати назву «клієнт» (коли йдеться про профілактику хвороб чи підтримку наявного стану здоров'я) чи «пацієнт» (коли йдеться про відновлення здоров'я, його покращення, надання медичної допомоги). Недоліком нормативного врегулювання статусу цієї сторони в наукових джерелах

\footnotetext{
31 Більш детально див. : Булеца С. Договір про надання особливих послуг. Порівняльне аналітичне право. 2017. № 6. С. 90-93.

32 Більш детально див. : Абрамович Н. Особливості укладення, зміни та припинення договору про надання медичних послуг. Підприємництво, господарство і право. 2017. № 4. С. 4-7.
} 
вказується також на одночасне вживання в одному нормативному акті таких категорій, як «людина», «особа», «пацієнт» ${ }^{33}$. Щодо другої сторони договору, їі назва може бути й такою, як це пропонує ЦК України щодо договорів про надання послуг, - «виконавець». I вже залежно від того, про якого суб'єкта йдеться (медична установа або фізична особа-підприємець, яка має право надавати медичні послуги), може бути деталізована в договорі.

Питання відповідальності за порушення умов договору про надання медичних послуг є найважливішими, на наш погляд, у таких договорах. Звісно, у ЦК України є норми, якими регулюються питання відшкодування збитків, натомість це стосується недоговірних зобов'язань. Якщо ж ідеться про досягнені сторонами домовленості, незалежно від того, чи були вони викладені в письмовій формі, чи були досягнені в усній формі, необхідне додаткове нормативне, чітке й імперативне врегулювання питань відповідальності за їх невиконання або неналежне виконання. Можливе також диспозитивне врегулювання, але зміна встановленої законом міри відповідальності може бути дозволена лише в частині їі збільшення. Нині норми Основ законодавства України про охорону здоров'я в частині встановлення відповідальності закріплені досить узагальнено, у них не вміщується конкретної інформації про відповідальність, а лише здійснюється посилання на законодавство загалом. Так, у ст. 80 Основ законодавства України про охорону здоров'я закріплено, що особи, винні в порушенні законодавства про охорону здоров'я, несуть цивільну, адміністративну або кримінальну відповідальність згідно із законодавством ${ }^{34}$. Аналіз норм про відповідальність сторін за порушення умов договору про надання послуг, які закріплені у ЦК України, дає підстави говорити про можливість відшкодувати лише збитки, наявність яких треба довести. Зокрема, у ст. 906 ЦК України йдеться про: 1) випадки, коли можливим стає пред'явлення вимог про відшкодування (невиконання або неналежне виконання договору про надання послуг); 2) різновиди договорів, у яких можливе пред'явлення таких вимог (лише оплатні); 3) сторону, яка може пред'являти вимоги про відшкодування збитків (лише замовник); 4) умови, за наявності яких стає можливим пред'явлення таких вимог (наявність вини виконавця); 5) обсяг збитків, який підлягає відшкодуванню (загальне правило - у повному обсязі), та можливий виняток із цього загального правила (зазначення іншого обсягу в умовах

\footnotetext{
${ }^{33}$ Самілик Л. Правовий статус суб'єктів медичного права. Порівняльно-аналітичне право. 2018 . № 1. C. 111-114.

34 Основи законодавства України про охорону здоров'я : Закон України від 19 листопада 1992 р. (із змінами). URL: https://zakon.rada.gov.ua/laws/main/2801-12 (дата звернення: 19.05.2020).
} 
договору, що означає можливість його зменшення) ${ }^{35}$. Окремо врегульовано особливості відповідальності виконавців, які надають послуги, перебуваючи у статусі підприємців. У разі порушення договорів про надання послуг такими виконавцями, за умови оплатності таких договорів, вони мають нести відповідальність за порушення умов договору (щоправда, у ЦК України це положення не деталізовано), а підставою для звільнення від відповідальності $\epsilon$ неможливість надання відповідної послуги (або інших зобов'язань, які були зазначені в договорі про надання послуги) унаслідок обставин непереборної сили, що, по-перше, має бути доведено таким підприємцем, по-друге, це законодавче положення сформульовано таким чином, що може бути змінено умовами конкретного договору або положеннями іншого закону. Щодо безоплатних договорів про надання послуг, у разі невиконання або неналежного виконання їхніх умов також можливе пред'явлення вимог про відшкодування збитків, водночас законодавець встановлює верхню (максимальну) межу щодо розміру відшкодування таких збитків - два неоподатковуваних мінімуми доходів громадян. Відповідна норма сформульована диспозитивним способом, що означає, що сторони відповідного договору можуть збільшити цей розмір. Щоправда, на практиці такі договори навряд чи матимуть місце, принаймні не будуть розповсюдженими у застосуванні, адже, зважаючи на безоплатний характер таких договорів, навряд виконавець погодиться на підвищення обсягу своєї відповідальності, зважаючи на те, що послуги ним надаються на безоплатній основі. Також варто зважати на те, що «додаткове (спеціальне) правове регулювання договірної цивільно-правової відповідальності здійснюється на підставі норм Закону України «Про захист прав споживачів», наставатиме за невиконання або неналежне виконання сторонами договору про надання медичних послуг його положень ${ }^{36}$.

\section{ВИСНОВКИ}

Специфічність рис медичних послуг, які не дозволяють їх «змішувати» 3 іншими різновидами цивільно-правових послуг, пов'язана з: 1) особливістю предмета нормативного регулювання (комплексний характер базового поняття «здоров'я», яке «зачіпає», «пронизує» чимало сфер правового регулювання); 2) нормативним аспектом (наявність спеціалізованого законодавства, яке включає нормативно-правові акти

\footnotetext{
35 Цивільний кодекс України від 16 січня 2003 p. (із змінами). URL: https://zakon.rada.gov.ua/ laws/show/435-15 (дата звернення: 19.05.2020).

${ }^{36}$ Сенюта I. Цивільно-правова відповідальність у сфері надання медичної допомоги : методичні рекомендації для адвокатів. Харків : Фактор, 2018. 64 с. С. 30.
} 
різної юридичної сили, від кодифікованих актів та простих законів до підзаконних актів, і ЦК України є лише одним із цих нормативних актів. Питання охорони здоров'я регулюються й іншими кодифікованими актами, серед яких і згадувані вище Основи законодавства України про охорону здоров'я. Коли ж ідеться вже про захист права на охорону здоров'я, залучаються також норми Кодексу України про адміністративні правопорушення, Кримінального кодексу України тощо (задіюються лише в разі скоєння протиправних дій у цій сфері); 3) доцільністю вживання специфічної термінології, особливо коли йдеться про суб'єктний склад цих договірних відносин, що пов'язано зі специфікою конкретної послуги, яка надається.

Аналіз нормативного регулювання питань, пов'язаних 3 укладанням, зміною, припиненням цивільно-правових договорів про надання медичних послуг, дозволив виявити чимало проблем у такому нормативному врегулюванні, що насамперед пов'язано 3 відсутністю в якомусь кодифікованому акті (ЦК України або Основи законодавства України про охорону здоров'я) окремого розділу про договірні відносини з надання медичних послуг. Ті норми про договори з медичного обслуговування, які нині закріплені в Основах законодавства України про охорону здоров'я, регулюють дещо інші аспекти надання медичних послуг, не пов'язані 3 конкретними випадками звернення замовника/клієнта/пацієнта до виконавця за наданням конкретної медичної послуги, отже, з виникненням цивільних договірних правовідносин. Проведений аналіз дозволяє констатувати необхідність удосконалення норм, яке пов'язане: 1) зі зміною підходів до наявної термінології; 2) з необхідністю закріплення норм про договори 3 надання медичних послуг у ЦК України як кодифікованому акті, у якому зібрано більшість норм, якими регулюються цивільно-правові договірні відносини; 3) з необхідністю закріплення обов'язкової письмової форми договорів про надання медичних послуг із можливістю застосування таких наслідків, як визнання його недійсним; 4) 3 необхідністю встановлення переліку обов'язкових (істотних) умов, серед яких предмет, права й обов'язки сторін та відповідальність. Щодо можливої дефініції договору про надання медичних послуг, в ії основу може бути покладена та дефініція, яка нині визначає договір про надання послуг у ЦК України.

\section{АНОТАЦІЯ}

У статті аналізуються ознаки медичних послуг, наводиться обгрунтування їхньої цивільно-правової природи. Зважаючи на важливість та специфічність об'єкта, з яким пов'язане надання послуги (здоров'я 
людини), обгрунтовується доцільність чіткого врегулювання договірних відносин, які мають місце кожного разу, коли відповідна послуга надається. Акцентується на необхідності закріплення в Цивільному кодексі України окремої глави в підрозділі «Договірні зобов'язання», де частина норм має закріплюватись імперативно, а диспозитивні норми мають дозволяти врегулювання конкретних відносин лише в бік підвищення прав i гарантій замовника/клієнта/пацієнта. Аналізуються положення законодавства 3 питань медичного обслуговування, охорони здоров'я, договірного регулювання відносин сторін, пропозиції, наявні в сучасних фахових наукових джерелах, 3 питань належного врегулювання й оформлення договірних відносин між замовниками/пацієнтами/клієнтами, 3 одного боку, та медичними установами, фізичними особамипідприємцями, які надають послуги 3 медичного обслуговування, 3 іншого боку, обгрунтовується необхідність як нормотворення, так і вдосконалення вже наявних норм із питань врегулювання договірних відносин із надання медичних послуг.

\section{ЛITЕРАТУРА}

1. Конституція України від 28 червня 1996 р. (із змінами). URL: https://zakon.rada.gov.ua/laws/show/254\%D0\%BA/96-

$\% \mathrm{D} 0 \% \mathrm{~B} 2 \% \mathrm{D} 1 \% 80$ ?find $=1 \&$ text=\%D0\%BD\%D0\%B0\%D0\%B9\%D0\%B2\%D 0\%B8\%D1\%89\#w11 (дата звернення: 19.05.2020).

2. Основи законодавства України про охорону здоров'я : Закон України від 19 листопада 1992 р. № 2801-XII (із змінами). URL: https://zakon.rada.gov.ua/ laws/main/2801-12 (дата звернення: 19.05.2020).

3. Болокан И. Здоровье как объект гражданско-правовой охраны и защиты. Правовая культура в современном обществе : сборник научных статей. Могилев : Могилевский институт МВД, 2019. С. 147-152.

4. Булеца С. Цивільні правовідносини, що виникають у сфері здійснення медичної діяльності: теоретичні та практичні проблеми : автореф. дис. ... докт. юрид. наук: 12.00.03. Одеса, 2016. 40 с.

5. Савченко В. Медичні послуги як об'єкт цивільних правовідносин : автореф. дис. ... канд. юрид. наук: 12.00.03. Київ, 2014. 20 с.

6. Самофал М. Цивільно-правове регулювання надання медичних послуг дітям : автореф. дис. ... канд. юрид. наук: 12.00.03. Київ, 2014. 18 с.

7. Герц А. Договірні зобов'язання у сфері надання медичних послуг : дис. ... докт. юрид. наук: 12.00.03. Київ, 2016. 421 с.

8. Смотров О. Договір щодо сплатного надання медичних послуг : автореф. дис. ... канд. юрид. наук: 12.00.03. Харків, 2003. 20 с. 
9. Волинець Т. Цивільно-правові засоби здійснення права на медичну допомогу : автореф. дис. ... канд. юрид. наук: 12.00.03. Львів, 2008. 16 с.

10. Тараненко А. Договір на протезування органів та кінцівок людини : дис. ... канд. юрид. наук: 12.00.03. Київ, 2015. 253 с.

11. Книш С. Юридична відповідальність за правопорушення у сфері охорони здоров'я в Україні. Право і безпека. 2018. № 4 (71). С. 43-49. DOI: 10.32631/pb2018.4.05.

12. Микитенко Д., Гомля I. Проблемні питання відповідальності за шкоду завдану при вакцинації. Мистещтво наукової думки. 2018. № 1. C. $140-143$.

13. Майкут Х. До питання цивільно-правової відповідальності у сфері медичної діяльності. Науковий вісник Херсонського державного університету. Серія «Юридичні науки». 2017. Вип. 1. Т. 1. С. 88-91.

14. Кушнір В., Коробцова Н. До питання цивільно-правової відповідальності у сфері надання медичних послуг. Молодий вчений. 2019. № 11 (75). C. 42-46. DOI: 10.32839/2304-5809/2019-11-75-10.

15. Михайлов С. Цивільно-правова відповідальність у сфері надання медичних послуг : автореф. дис. ... канд. юрид. наук: 12.00.03. Харків, 2010. $17 \mathrm{c}$.

16. Оверко Г. Відшкодування моральної шкоди, заподіяної при наданні медичних послуг в Україні : автореф. дис. ... канд. юрид. наук: 12.00.03. Київ, 2012. 19 с.

17. Пташник I. Трансплантація органів як особливий вид медичної послуги. Актуальні проблеми вдосконалення чинного законодавства Украӥни. 2016. Вип. 41. С. 16-26.

18. Болокан І. Послуги нетрадиційної медицини як різновид цивільноправових послуг. Запорізькі правові читання : матеріали щорічної Міжнародної науково-практичної конференції, м. Запоріжжя, 6 травня 2019 р. Запоріжжя : ЗНУ, 2019. 137 с. С. 12-16.

19. Скрипник В. Послуги як особливий об'єкт цивільних прав. Науковий вісник Міжнародного гуманітарного університету. Серія «Юриспрудениія». 2018. № 36. Т. 2. С. 38-41.

20. Цивільний кодекс України від 16 січня 2003 р. (із змінами). URL: https://zakon.rada.gov.ua/laws/show/435-15 (дата звернення: 19.05.2020).

21. Федорченко Н. До питання про предмет договору про надання послуг. Держава і право. Юридичні і політичні науки. 2014. Вип. 66. C. $165-173$.

22. Савченко В. Характерні правові ознаки медичних послуг. VIII Міжнародна наукова Internet-конферениії студентів та молодих вчених. Харків : ХНУ імені В.Н. Каразіна, 2013. С. 451-453. URL: 
http://dspace.univer.kharkov.ua/handle/123456789/8486 (дата звернення: 19.05.2020).

23. Майданник Р., Пермяков Б. Договір про надання медичних послуг. Аномалії в иивільному праві України : навчально-практичний посібник / за заг. ред. Р. Майданника. 2-ге вид., перероб. та доп. Київ : Юстініан, 2010. 1008 с. С. $279-315$.

24. Великий тлумачний словник української мови / упоряд. Т. Ковальова. Харків : Фоліо, 2005. 767 с.

25. Майданник Р. Договір про надання медичних послуг : загальні положення. Медичне право. 2016. № 1 (16). С. 139-158.

26. Герц А. Ціна як істотна умова договору про надання платних медичних послуг. Юридичний вісник. 2015. № 1. С. 115-118.

27. Щодо укладання договорів про надання платних медичних послуг. URL: https://kr.gov.ua/ua/news/pg/220917308767281_s/ (дата звернення: 19.05.2020).

28. Булеца С. Договір про надання особливих послуг. Порівняльне аналітичне право. 2017. № 6. С. 90-93.

29. Абрамович Н. Особливості укладення, зміни та припинення договору про надання медичних послуг. Підприємництво, господарство $i$ право. 2017. № 4. С. 4-7.

30. Самілик Л. Правовий статус суб'єктів медичного права. Порівняльно-аналітичне право. 2018. № 1. С. 111-114.

31. Сенюта I. Цивільно-правова відповідальність у сфері надання медичної допомоги : методичні рекомендації для адвокатів. Харків : Фактор, 2018. 64 с.

\section{Information about author:} Bolokan I. V., orcid.org/0000-0003-1868-7552 $\mathrm{PhD}$ hab. (Law), Associate Professor, Professor at the Department of Civil Law

Zaporizhzhya National University 66, Zhukovskoho str., Zaporizhzhia, 69002, Ukraine 